\author{
Marquette University \\ e-Publications@Marquette
}

College of Education Faculty Research and

Publications

Education, College of

$11-2005$

\title{
Depression and Contributors to Vocational Satisfaction in Roman Catholic Secular Clergy
}

\author{
Sarah Knox \\ Marquette University, sarah.knox@marquette.edu \\ Stephen G. Virginia \\ Tribunal of the Roman Catholic Diocese of Columbus, Ohio \\ Jessica A. Thull \\ Marquette University \\ John P. Lombardo \\ Marquette University, john.lombardo@marquette.edu
}

Follow this and additional works at: https://epublications.marquette.edu/edu_fac

Part of the Education Commons

\section{Recommended Citation}

Knox, Sarah; Virginia, Stephen G.; Thull, Jessica A.; and Lombardo, John P., "Depression and Contributors to Vocational Satisfaction in Roman Catholic Secular Clergy" (2005). College of Education Faculty

Research and Publications. 21.

https://epublications.marquette.edu/edu_fac/21 


\title{
Depression and Contributors to Vocational Satisfaction in Roman Catholic Secular Clergy
}

\author{
Sarah Knox ${ }^{1,3}$ \\ School of Education, Marquette University \\ Milwaukee, WI \\ Stephen G. Virginia² \\ Tribunal of the Roman Catholic Diocese of Columbus, Ohio \\ Jessica Thull \\ School of Education, Marquette University \\ Milwaukee, WI \\ John P. Lombardo \\ School of Education, Marquette University \\ Milwaukee, WI
}

A nationally selected, random sample of Roman Catholic secular (i.e., diocesan) priests was examined using the Center for Epidemiological StudiesDepression scale and an instrument developed for this study to assess contributors to priests' vocational satisfaction. In addition, a self-report inventory gathered information regarding participants' demographics as well as four categories of predictor variables (i.e., overall level of vocational satisfaction, social support, spiritual activities, physical environment). The study yielded a response rate of $45 \%$. Secular clergy reported rates of depression approximately seven times greater than are found in the general population, and also indicated that the recent sexual abuse scandal in the Roman Catholic Church had negatively affected their mood. Priests' engagement in sacramental activities contributed greatly to their vocational 
satisfaction, and low levels of vocational satisfaction were found to be most predictive of depression. Factors comprising priests' vocational satisfaction were External Manifestations (e.g., preaching, teaching), Internal Manifestations (e.g., prayer life, affirmation of God's call), and Social Manifestations (e.g., relationships with parishioners, appreciation from others).

\section{Introduction}

The vocational demands experienced by Roman Catholic secular clergy (i.e., diocesan priests who serve in parochial settings in the secular society) in the U.S. continue to increase, for while their own numbers age and decline, the numbers of parishioners increases. Approximately $23 \%$ of the country's population identifies as Roman Catholic (Kenedy \& Sons, 2003), equating to 66,407,105 million persons. Serving these millions, however, are only approximately 29,715 secular priests, indicating a decrease of more than 3761 , or almost $13 \%$, of the secular priest population in the last 10 years (Kenedy \& Sons, 2003). If this trend were to continue, one arising from priests' deaths, departures from the priesthood, and low numbers of men entering the priesthood, there may soon be alarmingly few Roman Catholic priests in the U.S., whether secular or religious ordered. In the meantime, those who continue in their vocation will surely be expected to provide a growing range of services to an increasing priest-to-parishioner ratio. Many priests, even now, report being overwhelmed by their vocational responsibilities (Rossetti, 2004). Such demands heighten already existing challenges in priests' pastoral duties, and may render priests vulnerable to psychological distress, as well as to decreased satisfaction with their vocation.

Despite the bleak picture herein painted, Roman Catholic secular priests in the U.S. have garnered minimal empirical attention. In what scant research has focused on this population, Virginia (1998) found that Roman Catholic secular clergy reported significantly greater emotional exhaustion and depression than their religious ordered brethren. Key contributing factors appear to be secular clergy's reported lack of social support and sense of isolation.

Virginia and his colleagues later extended this research to investigate not only priests' levels of depression, but also their levels

Pastoral Psychology, Vol. 54, No. 2 (November 2005): pg. 139-155. DOI. This article is @ Springer and permission has been granted for this version to appear in e-Publications@Marquette. Springer does not grant permission for this article to be further copied/distributed or hosted elsewhere without the express permission from Springer. 
of anxiety, a construct that had not yet been examined in the clerical population. Their study deliberately focused, however, only on secular clergy. Comprising the majority of the Roman Catholic clergy, these individuals live in the secular community and thus may reflect more normative experiences. Through their work in parishes, they also carry the greatest pastoral responsibility for Roman Catholics in the U.S. The researchers found that Roman Catholic secular clergy reported significantly greater depression and anxiety (both state and trait) than the general population. In addition, low overall vocational satisfaction (assessed in the study via a single question) was predictive of depression, as well as both forms of anxiety (Knox, Virginia, \& Lombardo, 2002).

From such research, then, we know that Roman Catholic secular clergy have recently reported high levels of emotional exhaustion, depression, and anxiety. Of particular interest in this last study (i.e., Knox et al., 2002), as well, was the finding regarding vocational satisfaction: Low vocational satisfaction predicted depression. Given that vocational satisfaction was assessed through a single item (i.e., "Please circle one of the numbers below to rate your self-evaluation of your personal degree of vocational satisfaction as a priest in your present situation"), we were curious as to what priests considered when answering this question. In essence, we wanted to know what contributes to the vocational satisfaction of Roman Catholic secular clergy, for understanding such contributors may identify means through which priests' vocational satisfaction may be increased, and their psychological distress reduced.

Consistent with the lack of empirical literature regarding Roman Catholic secular clergy in the U.S. in general, there also exists little research about priests' vocational satisfaction. One study (Pallone, 1969) investigated the correlates of vocational satisfaction among Catholic brothers (i.e., Brothers' Society, congregation of the Holy Cross). Pallone theorized that vocational satisfaction could be approximated by examining the congruence between an individual's self-concept and his perception of the "ideal" occupant of the religious role he was preparing to enter, with greater congruence suggesting higher vocational satisfaction. He found that both his more and less vocationally satisfied participants perceived themselves and the "ideal"

Pastoral Psychology, Vol. 54, No. 2 (November 2005): pg. 139-155. DOI. This article is @ Springer and permission has been granted for this version to appear in e-Publications@Marquette. Springer does not grant permission for this article to be further copied/distributed or hosted elsewhere without the express permission from Springer. 
brother in a relatively uniform way: They agreed not only in their perceptions of the "ideal" brother, but also viewed themselves as very similar persons. Vocational satisfaction, according to Pallone, thus resided in the relationship between self and role. More satisfied brothers did demonstrate higher superego strength, scientific interest, and more often had graduated from schools run by the community of which they were now members than had their less satisfied brethren.

A more recent study (LeNoir, 2001) used a model of marital processing to examine vocational satisfaction among active and nonactive (i.e., those who had left the ministry) Roman Catholic secular priests. LeNoir found that priests' family of origin and coping strategy in managing stress were predictive of vocational satisfaction. Beyond these two investigations, little is known regarding the vocational satisfaction of Roman Catholic clergy. Given the increasing demands placed on such persons, as well as the evidence of alarming levels of psychological distress already reported in this population, it is thus essential that we seek to better understand priests' vocational lives.

We cannot ignore, as well, the recent scandal in which the Roman Catholic Church in the U.S. has been involved, and wonder about its effects on both depression and vocational satisfaction among the clergy. More than 1200 priests have been named as potential abusers of over 4000 minors, involving all but 16 of the 177 Latin Rite dioceses in the United States (Goodstein, 2003). While the majority of priests have not been implicated in this abuse, they may nevertheless now be subject to suspicion and mistrust, which may well take a toll on their psychological health.

This study, then, sought to investigate the degree to which Roman Catholic secular priests report symptoms of depression, and also endeavored to understand the factors that contribute to their vocational satisfaction. Depression was assessed through the Center for Epidemiological Studies-Depression (CES-D; Radloff, 1977) scale; contributors to vocational satisfaction were assessed through a 12item questionnaire developed for this study. Additionally, via the SelfReport Inventory (SRI; Virginia, 1998), the research examined four classes of predictor variables (i.e., overall level of vocational

Pastoral Psychology, Vol. 54, No. 2 (November 2005): pg. 139-155. DOI. This article is @ Springer and permission has been granted for this version to appear in e-Publications@Marquette. Springer does not grant permission for this article to be further copied/distributed or hosted elsewhere without the express permission from Springer. 
satisfaction, social support, spiritual life, and physical environment), as well as demographics of age, years in priesthood, and numbers of clergy with whom participants live, and correlated each feature of each predictor/demographic variable with the measures of depression and vocational satisfaction.

\section{Method}

\section{Participants}

Participants were 500 Roman Catholic secular clergy residing in the United States, randomly selected from The Official Catholic Directory (Kenedy \& Sons, 2003). Overall, a total of 225 surveys were returned, for a response rate of $45 \%$, including those who responded but declined to participate $(n=9)$. The initial mailing yielded a usable response rate of $29 \%(n=146)$, and the follow-up mailing yielded an additional $14 \%(n=70)$. Thus, data from $43 \%$ of the original sample of 500 ( $N=216$ participants) were used in the analyses.

\section{Measures}

A survey questionnaire packet, addressed by hand, was mailed to each potential participant. This packet contained a cover letter describing the study and explaining the individual's right to refuse participation, as well as procedures for confidentiality. The enclosed instruments included the 15-item Self-Report Inventory to gather basic demographic information and assess the four classes of predictor variables; the 20 questions that constitute the CES-D (the depression instrument); and the 12 items of the vocational satisfaction instrument. Thus, there were 47 questions in total.

The Self-Report Inventory (SRI; Virginia, 1998) contains 15 questions, the first 4 of which ask for demographic information (i.e., age, race, years of priesthood, number of clergy and/or religious with whom the participant currently lives). Among the remaining questions, one asks participants to indicate their overall level of current vocational satisfaction, four address social support, four address spiritual life, and two address physical environment. These items are scored on a seven-point Likert scale, with the lowest anchor (i.e., 0)

Pastoral Psychology, Vol. 54, No. 2 (November 2005): pg. 139-155. DOI. This article is @ Springer and permission has been granted for this version to appear in e-Publications@Marquette. Springer does not grant permission for this article to be further copied/distributed or hosted elsewhere without the express permission from Springer. 
indicating the absence/lack of the construct being measured (e.g., vocational satisfaction, social support, etc.), and the highest anchor (i.e., 6) indicating total, extreme, or great presence of the construct.

The CES-D is a 20-question self-report instrument developed to assess depressive symptomatology within the general population (Radloff, 1977). It is also used to investigate relationships between depression and other variables across populations (Radloff, 1977), and thus was quite appropriate for the current study. Using a four-point Likert scale where $0=$ Rarely or None of the Time (Less than 1 day), 1 = Some or Little of the Time (1-2 days), 2 = Occasionally or a Moderate Amount of Time (3-4 days), and $3=$ Most or All of the Time (5-7 days), participants respond to questions such as "I did not feel like eating; my appetite was poor," "I had trouble keeping my mind on what I was doing," "I thought my life had been a failure," "I felt lonely," "My sleep was restless," or "I felt that people dislike me," basing their responses on how they felt during the last week. Higher scores indicate greater depressive symptomatology, with a maximum possible score of 60. Radloff (1977) established a cutoff score of 16 or higher as indicative of depressed mood. Studies have found reliability coefficients ranging from .80 to .88 for the instrument (Beeber, Shea, \& McCorkle, 1998; Knight, Williams, McGee, \& Olaman, 1997; Scott \& Melin, 1998). In addition, convergent validity has been supported through the instrument's correlation with other measures of depression (Radloff, 1977; Weissman, Sholomskas, Pottenger, Prusoff, \& Locke, 1977). Coyle and Roberge (1992) found that the CES-D had good factorial validity, and Weissman et al. found the CES-D to have an excellent rating (i.e., greater than .90) in its ability to distinguish depressed from nondepressed individuals. CES-D reliability (i.e., Cronbach's alpha) was .87.

The Vocational Satisfaction Instrument (VSI) was developed for this study. Eighteen colleagues or associates of the second author, himself a secular priest, completed a pilot survey in which they were asked to complete the sentence stem "Vocational satisfaction is . . ." with as many different responses as possible. These 18 surveys were then reviewed by the first and second authors, and core themes among the responses identified. Those core themes then served as the basis for the 12 items of the vocational satisfaction instrument here

Pastoral Psychology, Vol. 54, No. 2 (November 2005): pg. 139-155. DOI. This article is @ Springer and permission has been granted for this version to appear in e-Publications@Marquette. Springer does not grant permission for this article to be further copied/distributed or hosted elsewhere without the express permission from Springer. 
developed. In responding to each item, participants were asked to indicate the degree to which the item's content contributed to their vocational satisfaction, using a scale of $0=$ does not contribute at all, $3=$ moderately contributes, and $6=$ highly contributes. Examples of items include "My relationships with my parishioners," "My teaching activities," "My sense of being appreciated by others," and "The affirmation of God's call to me to enter this vocation." The VSI, then, was designed to assess the contributors to priests' vocational satisfaction; it did not assess their level of vocational satisfaction. Cronbach's alpha for the VSI in the current study was $a=.82$.

\section{Sexual Abuse Question}

Using a seven-point scale $(-3=$ Much Worse, $0=$ No Change, $+3=$ Much Better), we asked a single question to assess the effect, if any, of the recent sexual abuse scandal on participants' mood (i.e., "Using the scale below, please indicate the extent to which your mood has been affected by the recent sexual abuse scandal in the Roman Catholic Church."). For all statistical analyses, raw scores were transformed by adding three points to each participant's response (i.e., $0=$ Much Worse, $3=$ No Change, $6=$ Much Better).

\section{Results}

\section{The Self-Report Inventory (SRI)}

With regard to basic demographics, the mean age of the sample was $M=56.66(S D=12.64)$ years. The sample reported a mean of $M$ $=27.22(S D=14.46)$ years in the priesthood and lived with a mean of $M=1.45(S D=2.13)$ other religious or clergy.

Similar to previous studies with this population (e.g., Knox et al., 2002), White/European-Americans comprised $91.67 \%$ of the sample, others (mostly Hispanic/Latino Americans) 3.70\%, Black/African-Americans 2.78\%, Asian-Americans 1.39\%, and those reporting two or more races less than one-half percent. Also similar to this previous study, we found that non-White/European-American participants were significantly younger and reported fewer years in the priesthood than their White/European-American peers. With no

Pastoral Psychology, Vol. 54, No. 2 (November 2005): pg. 139-155. DOI. This article is @ Springer and permission has been granted for this version to appear in e-Publications@Marquette. Springer does not grant permission for this article to be further copied/distributed or hosted elsewhere without the express permission from Springer. 
evidence of additional racial differences (e.g., rates of depression, response to sexual abuse question), and the small representative numbers of minority participants (less than $9 \%$ of the total), we did not include race classification as a variable in any of the subsequent analyses.

The first of the four classes of predictor variables on the SRI assessed priests' overall level of Vocational Satisfaction. [Note: Level of Vocational Satisfaction was assessed on the SRI via a single question, in contrast to the VSI (see below), which was an entire instrument devoted to assessing the contributors to priests' vocational satisfaction.] Using a Likert scale where $0=$ No Satisfaction and $6=$ Total Satisfaction, respondents reported a vocational satisfaction of $M$ $=4.77(S D=1.14)$. Thus, these participants were fairly satisfied with their vocation.

The second class of predictor variable measured the presence of Social Support. Using a Likert scale where $0=$ No Support and $6=$ Total Support, the sample indicated support from superiors at $M=$ $3.84(S D=1.68)$ and from peers at $M=4.22(S D=1.36)$. Using a Likert scale where $0=$ No Opportunity and $6=$ Great Opportunity to be in the company of other priests outside of formal ecclesiastical or liturgical duties, the mean for participants was $M=3.35(S D=1.61)$. On a Likert scale where $0=$ Not Easy at All and $6=$ Great Ease to discuss a concern about work or vocation with someone who will help, the sample's mean was $M=4.16(S D=1.51)$. These participants, then, reported receiving social support from superiors and peers, enjoyed at least some opportunity to be in the company of other priests outside of clerical duties, and frequently could discuss work or vocational concerns with those who would help.

The third class of predictor variable examined priests' Spiritual Life. On a Likert scale where $0=$ No Importance and $6=$ Great Importance of the role of silence in life, the mean was $M=4.79$ ( $S D=$ 1.20). When responding to a question about degree of difficulty completing the Divine Office daily, where $0=$ No Difficulty and $6=$ Great Difficulty, the mean was $M=3.19$ ( $S D=2.07)$. In rating the degree of use of a spiritual director, where $0=$ Very Little and $6=$ Very Great, the mean was $M=2.66(S D=1.95)$. Finally, respondents'

Pastoral Psychology, Vol. 54, No. 2 (November 2005): pg. 139-155. DOI. This article is @ Springer and permission has been granted for this version to appear in e-Publications@Marquette. Springer does not grant permission for this article to be further copied/distributed or hosted elsewhere without the express permission from Springer. 
indicated that they engaged in a mean of $M=49.79(S D=40.19)$ minutes of non-duty spiritual reading daily. Current participants thus indicated that silence was important to their spiritual life, evinced moderate difficulty completing the daily Divine Office, seldom used a spiritual director, and engaged in less than one hour of chosen spiritual reading each day.

The fourth class of predictor variable assessed the importance of the Physical Environment. When rating the perceived degree of importance of the physical environment on vocation as a priest, where $0=$ No Importance and $6=$ Extremely Important, the mean was $M=$ 4.35 ( $S D=1.27)$. When assessing priests' perception of the impact that the physical environment plays in prayer life, where $0=$ No Importance and $6=$ Great Importance, the mean was $M=4.10$ ( $S D=$ 1.34). Here, then, priests reported that not only was their physical environment important to their vocation, but that it also had a noticeable effect on their prayer life.

\section{The CES-D}

The mean for the CES-D was $M=9.61(S D=7.62)$. The sample revealed that $18 \%(n=38$; out of 216$)$ met or exceeded the established cutoff for depression. Thus, almost one-fifth of the respondents met the threshold for depression.

\section{The Vocational Satisfaction Instrument (VSI)}

As indicated above, the VSI asked participants to rate 12 items on a 7-point Likert scale ( $0=$ Does Not Contribute at All, $3=$ Moderately Contributes, $6=$ Highly Contributes) with respect to how much that item contributed to his vocational satisfaction. Item means and standard deviations are as follows: Involvements in Sacraments $(M=5.36, S D=.83)$, Preaching Activities $(M=5.14, S D=1.06)$, Opportunity to Share the Presence of God or Goodness with Others ( $M$ $=5.10, S D=.89)$, Affirmation of God's Call to Vocation $(M=5.04, S D$ $=1.21)$, Relationships with Parishioners $(M=5.04, S D=1.05)$, Opportunities to Help Others $(M=5.00, S D=.91)$, My Prayer Life $(M$ $=4.97, S D=1.11$ ),

Pastoral Psychology, Vol. 54, No. 2 (November 2005): pg. 139-155. DOI. This article is (c Springer and permission has been granted for this version to appear in e-Publications@Marquette. Springer does not grant permission for this article to be further copied/distributed or hosted elsewhere without the express permission from Springer. 
Teaching Activities $(M=4.47, S D=1.39)$, Sense of Being Appreciated by Others $(M=4.33, S D=1.25)$, Parish Activities $(M=$ $4.31, S D=1.16)$, Opportunities to Experience Transcendence $(M=$ $4.28, S D=1.42)$, and Relationships with Fellow Clergy $(M=3.66, S D$ $=1.69)$.

\section{Sexual Abuse Question}

The mean for this item, in which participants indicated the extent to which their mood had been affected by the recent sexual abuse scandal in the Roman Catholic Church, where $0=$ Much Worse, $3=$ No Change, and $6=$ Much Better, was $M=2.20(S D=1.19)$. Such results indicate that the recent scandal had a deleterious effect on the mood of these priests.

\section{CES-D Multiple Regression with SRI Predictor Variables}

A stepwise regression was performed using SPSS ${ }^{x}$ to ascertain which SRI predictor variables accounted for the greatest variance in CES-D scores. Four significant predictor variables emerged (see also Table 1). After step 1, with overall level of Vocational Satisfaction in the equation, Adjusted $R^{2}=.37, F(1,167)=99.19, \mathrm{p}<.001$. After step 2, with Non-duty Opportunity for Company of Other Priests in the equation, Adjusted $R^{2}=.39, F(2,166)=55.29, \mathrm{p}<.001$. After step 3, with Years of Priesthood entered in the equation, Adjusted $R 2=.41, F$ $(3,165)=40.01, p<.001$. Finally, after step 4, with Ease of Discussion about Work or Vocational Concern entered in the equation, Adjusted $R^{2}$ $=.42, F(4,164)=31.73, \mathrm{p}<.001$. Thus, priests' level of vocational satisfaction was most highly related to depression (accounting for more than a third of the variance; specifically, those priests reporting greater vocational satisfaction were less likely to report being depressed), followed by their opportunities to spend time with other priests outside of their clerical duties, the length of time they had been priests, and the ease with which they could discuss vocational concerns with others.

Pastoral Psychology, Vol. 54, No. 2 (November 2005): pg. 139-155. DOI. This article is (C Springer and permission has been granted for this version to appear in e-Publications@Marquette. Springer does not grant permission for this article to be further copied/distributed or hosted elsewhere without the express permission from Springer. 


\section{SRI Vocational Satisfaction Question Multiple Regression with VSI}

A stepwise regression was performed using SPSS ${ }^{x}$ to ascertain which VSI predictor items accounted for the greatest variance in the SRI overall level of Vocational Satisfaction item. Four significant predictor items emerged (see also Table 2). After step 1, with Parish Activities in the equation, Adjusted $R^{2}=.19, F(1,178)=42.44$, $\mathrm{p}<.001$. After step 2, with Affirmation of God's Call to Vocation in the equation, Adjusted $R^{2}=.28, F(2,177)=35.32$, p <.001. After step 3, with Relationships with Fellow Clergy entered in the equation, Adjusted $R^{2}=.31, F(3,176)=28.23, \mathrm{p}<.001$. Finally, after step 4 , with Opportunity to Help Others entered in the equation, Adjusted $R^{2}=.34$, $F(4,175)=23.94, \mathrm{p}<.001$. Involvement in the parish, then, was most greatly related to priests' level of vocational satisfaction, followed by their sense that they had been called by God to the vocation, their relationships with their brethren, and their opportunities to help others.

\section{CES-D Multiple Regression with VSI and Sexual Abuse Question}

A stepwise regression was performed using SPSS ${ }^{\times}$to ascertain to what extent the VSI predictor items, as well as the Sexual Abuse question, accounted for variance on the CES-D. Six significant predictor items emerged (see also Table 3). After step 1, with Affirmation of God's Call to Vocation in the equation, Adjusted $R^{2}=$ $.12, F(1,195)=27.16, \mathrm{p}<.001$. After step 2, with Opportunities to Help Others in the equation, Adjusted $R^{2}=.17, F(2,194)=21.00$, $\mathrm{p}<.001$. After step 3, with Relationships with Parishioners in the equation, Adjusted $R^{2}=.20, F(3,193)=16.88, \mathrm{p}<.001$. After step 4, with Relationships with Fellow Clergy entered in the equation, Adjusted $R=.22, F(4,192)=14.39, \mathrm{p}<.001$. After step 5 , with the Sexual Abuse question entered in the equation, Adjusted $R^{2}=.23, F(5,191)$ $=12.68, \mathrm{p}<.001$. Finally, after step 6, with Preaching Activities entered in the equation, Adjusted $R^{2}=.24, F(6,190)=11.42$, $\mathrm{p}<.001$. Here, then, priests' depression was best explained by their sense that God had called them to the priesthood (i.e., the stronger

Pastoral Psychology, Vol. 54, No. 2 (November 2005): pg. 139-155. DOI. This article is @ Springer and permission has been granted for this version to appear in e-Publications@Marquette. Springer does not grant permission for this article to be further copied/distributed or hosted elsewhere without the express permission from Springer. 
the sense of call, the less likely to be depressed), and to a lesser extent also by their opportunities to help others, their relationships with parishioners and fellow clergy, the recent sexual abuse scandal, and their involvement in preaching.

\section{Exploratory Factor Analysis of VSI}

Cases with missing values on any of the VSI items were eliminated listwise, resulting in a total of 204 cases used in this analysis. Prior to the factor analysis, we performed two tests to ensure that the correlation matrix had variation suitable for factoring. First, we obtained a statistically significant value for Bartlett's test of Sphericity, $X^{2}(66, n=204)=695.66, p<.001$. Second, the KaiserMeyer-Olkin measure of sampling adequacy was 0.83 . Because we had no apriori hypotheses regarding the existence or nature of the factors, we chose to use a principal components analysis with varimax rotation on the 12 VSI items, a common approach in such circumstances.

Three factors emerged with eigenvalues greater than 1, and accounted for approximately $60 \%$ of the total variance. Table 4 shows a summary of the rotated factor analysis. The first factor, "External Manifestations," had the heaviest item loadings for preaching, teaching, and other externally observable activities of the secular priest, and accounted for more than $24 \%$ of the total variance. The second factor, "Internal Manifestations," accounting for over $19 \%$ of the variance, loaded most heavily for items involving priests' personal prayer lives, affirmation of God's call, relationships with fellow clergy, and the experience of transcendence. The third factor, "Social Manifestations," accounted for more than $13 \%$ of the variance, and loaded most heavily for relationships with parishioners, appreciation from others, and relationships with fellow clergy.

\section{Discussion}

As a brief overview, this sample of Roman Catholic secular clergy consisted predominantly of White/European American, middleaged men who had been in the priesthood for over two-and-a-half decades, and who lived with only one other member of the clergy. As a group, they were fairly satisfied with their vocation and experienced moderate degrees of social support. Silence generally had an

Pastoral Psychology, Vol. 54, No. 2 (November 2005): pg. 139-155. DOI. This article is @ Springer and permission has been granted for this version to appear in e-Publications@Marquette. Springer does not grant permission for this article to be further copied/distributed or hosted elsewhere without the express permission from Springer. 
important role in their spiritual lives (showing the highest mean for the SRI predictor variables), they reported moderate difficulty completing the Divine Office daily, and engaged in almost 50 minutes of non-duty spiritual reading each day. Relatively few participants reported using a spiritual director (showing the lowest mean for SRI predictor variables). They noted that their physical environment was moderately important to their lives. Finally, these participants indicated that sacramental activities, broadly defined, contributed greatly to their vocational satisfaction, a finding consistent with other research (Rossetti, 2004; also see below for full discussion of VSI findings).

Participants' responses in this study yielded a rate of depressed mood approximately seven times higher than that reported in the general population. Point prevalence for Major Depressive Disorder, which lists depressed mood in its first criterion, in an adult community sample has varied from 2-3\% for men (DSMIV-TR, 2000). As stated in the $D S M-I V-T R$, this prevalence rate appears to be unrelated to ethnicity, education, income, or marital status. Knox et al. (2002) and Virginia (1998) also found elevated rates of depression among their samples of Roman Catholic clergy. Thus, three recent studies have found secular priests to be significantly more depressed than the general population, a finding that may appropriately cause concern for the Roman Catholic Church. Of additional concern in the present study is also the finding that these priests' mood had been negatively affected by the recent sexual abuse scandal. To a population already expressing alarming rates of depression, this scandal may well have exacerbated their psychological distress.

With regard to the predictor variables of the SRI, priests' response to the single Vocational Satisfaction item (i.e., a rating of their overall level of vocational satisfaction) was most predictive of depression: Those respondents who reported lower vocational satisfaction also reported higher depression scores (i.e., greater depression) on the CES-D. This SRI variable appears to be consistently salient in predicting depression among Roman Catholic secular clergy, for it also was found most predictive of depression in earlier research (i.e., Knox et al., 2002). Such findings make intuitive sense, as well, for clergy who are vocationally satisfied are less likely to experience depression. In addition, three other SRI variables were also found to

Pastoral Psychology, Vol. 54, No. 2 (November 2005): pg. 139-155. DOI. This article is @ Springer and permission has been granted for this version to appear in e-Publications@Marquette. Springer does not grant permission for this article to be further copied/distributed or hosted elsewhere without the express permission from Springer. 
be predictive of depression: Non-duty Opportunity for the Company of Other Priests, Years of Priesthood, and Ease of Discussion about Work or Vocational Concern. The ability to enjoy the company of colleagues, as well as the opportunity to discuss with them vocational challenges, also appeared to have salutary effects on psychological distress. Furthermore, the longer a priest remained in the priesthood, the less likely he was to be depressed, an intriguing finding, indeed. Unfortunately, our data do not allow us to determine whether this finding reflects an exodus of depressed and/or dissatisfied priests from the clergy, whether priests' vocational satisfaction increases over time, or whether there may be other explanations for this finding.

Now with regard to the predictor variables of the VSI, priests' sense that they had been called by God to their vocation held the greatest predictive power for depression (i.e., higher endorsement of Affirmation of God's Call to Vocation was related to less depression), followed by their opportunities to help others and their relationships with parishioners and fellow clergy. Thus, the sense of a clear vocational direction, as well as the ability to serve and relate with others, seemed to ameliorate their psychological distress.

Similarly, priests' response to the Vocational Satisfaction item on the SRI was best predicted by four VSI items: Parish Activities, Affirmation of God's Call to Vocation, Relationships with Fellow Clergy, and Opportunity to Help Others. It appears, then, that priests' engagement in the life of the parish and in helping others, their sense that they have been divinely called to their vocation, and their relationships with colleagues are highly related to their level of vocational satisfaction. Involvement with others, as well as the sense that one is in the most fitting vocation, clearly contributed to these participants' satisfaction, and also appeared to reduce their levels of distress, as indicated above.

The factor analysis of the VSI yielded three components, one reflecting priests' external lives, another their internal lives, and the third their relationships with others. Collectively, these factors explained almost $60 \%$ of the variance. The factor accounting for the greatest variance (i.e., "External Manifestations") consists of many activities that are unique to clergy, such as preaching and sacramental

Pastoral Psychology, Vol. 54, No. 2 (November 2005): pg. 139-155. DOI. This article is @ Springer and permission has been granted for this version to appear in e-Publications@Marquette. Springer does not grant permission for this article to be further copied/distributed or hosted elsewhere without the express permission from Springer. 
involvement. The very functions that may draw one to pursue the priesthood, then, are those that appear to contribute most powerfully to vocational satisfaction. The second factor (i.e., "Internal Manifestations") reflects priests' inner world: their prayer life, the sense that God has called them to the priesthood, their experiences of transcendence. Not only, then, are outwardly observable elements important to priests' vocational satisfaction; so, too, is their internal world, their privately experienced sense of God's presence. Finally, priests' relationships with others (i.e., "Social Manifestations") were also crucial to their vocational satisfaction, a finding consistent with other research (Zickar, Balzer, Wryobeck, \& Aziz, 2004). They may thrive performing the sacraments, may enjoy a fulfilling prayer life, but clearly they need also to connect with others, both their clerical brethren and their parishioners. Thus, the external, internal, and social worlds are all vital to priests' vocational satisfaction.

These VSI findings are both similar to, and intriguingly different from, those reported in other research. Studies of vocational satisfaction among non-clergy populations have taken a path much like that we followed here: Researchers often begin with global indicators of vocational satisfaction (i.e., see the Vocational Satisfaction question on the SRI), and then seek to uncover more specific factors that underlie the global findings (i.e., see the VSI). Many such investigations have identified factors that do appear to contribute to the global measure (e.g., the nature of the work itself [similar to our "External" factor], work-related relationships [similar to our "Social" factor]). But despite such empirical substantiation, researchers have felt that the factors nevertheless fell short, or failed to capture something essential with respect to vocational satisfaction (Diener, 2000; Jepsen \& Sheu, 2003; Spector, 1997).

In response, investigators have recently begun to examine elements more internal to the worker, such as culture (Sharf, 2002), positive emotions and character strengths (Peterson \& Seligman, 2004), as well as spirituality and life values (Richards \& Bergin, 2000) as additional contributors to vocational satisfaction. We are not aware, however, of any research that has so directly assessed internal activities or experiences, as was included here in the VSI (e.g., questions regarding prayer life, sense of God's calling, experience of

Pastoral Psychology, Vol. 54, No. 2 (November 2005): pg. 139-155. DOI. This article is (c) Springer and permission has been granted for this version to appear in e-Publications@Marquette. Springer does not grant permission for this article to be further copied/distributed or hosted elsewhere without the express permission from Springer. 
transcendence). While it may not be surprising to find such features salient to priests' vocational satisfaction, the strength of this factor here may suggest that such internal experiences are of no less importance to the vocational satisfaction of non-clergy populations, as well.

\section{Implications}

In integrating these results, what do we find? First, we find a largely White/ European American, middle-aged group of U.S. secular priests who have been in their vocation for over a quarter of a century, and who report moderate degrees of vocational satisfaction and social support. As a group, however, they are alarmingly depressed, a status made worse by the recent sexual abuse scandal in the Roman Catholic Church. But all is not hopeless: Given the strong relationship found here between depression and level of vocational satisfaction, efforts to increase priests' vocational satisfaction may do much to ameliorate their psychological distress. And based on the results of the VSI, we now have some understanding of what contributes to priests' vocational satisfaction: their involvement in the life of the parish, their sense that they were called to this vocation by God, their relationships with fellow clergy, and the opportunity to help others. These results are thus pregnant with possibilities for reducing priests' depression: Enable priests to be deeply immersed in parish activities, especially through sacramental involvement; provide them with opportunities to experience, and re-experience, God's call, perhaps through the presence of silence (which they endorsed as having an important role in their spiritual lives) and of opportunities to serve others; and nurture their relationships with fellow clergy. When able to attend to external, internal, and social manifestations of vocational satisfaction, then, priests' psychological distress may be reduced.

\section{Limitations}

One limitation of this study is our response rate, which was lower than that reported in previous research conducted on Roman Catholic clergy (Knox et al., 2002; Virginia, 1994, 1998). Identical methodology was used across these investigations, with the only variant that Knox et al. (2002), as well as the current study, chose not

Pastoral Psychology, Vol. 54, No. 2 (November 2005): pg. 139-155. DOI. This article is (c Springer and permission has been granted for this version to appear in e-Publications@Marquette. Springer does not grant permission for this article to be further copied/distributed or hosted elsewhere without the express permission from Springer. 
to include a $\$ 2$ stipend. Both Knox et al. (2002) and the current study's response rates were lower than their predecessor that did include this stipend. Beyond the stipend, we remain unsure about what else may have contributed to this reduced rate of response, but wonder whether recent events (i.e., the sexual abuse scandal) may have made priests more leery about answering questionnaires.

In addition, the SRI was designed specifically for use in a prior study (i.e., Virginia, 1998). Although it demonstrates face validity, we lack empirical evidence regarding the operationalization of many of its constructs. Operationalization of vocational satisfaction, however, was one of the primary purposes of the present study. The instrument we developed (i.e., VSI) thus far lacks psychometric data regarding its reliability and validity.

\section{Future Directions}

This study made a first attempt to investigate those factors that may contribute to the vocational satisfaction of Roman Catholic secular clergy. Our hope is that this investigation is but the initial step toward understanding the influences on priests' vocational satisfaction. The VSI clearly needs to be subjected to much more scrutiny, on populations both similar to and different from the current sample, before we can assert that it reliably and validly assesses factors related to secular priests' vocational satisfaction. We encourage other researchers to begin such scrutiny.

In addition, one of the intriguing findings reported here was that the longer priests remained in their vocation, the less likely they were to be depressed. We do not know, however, what may explain this result: It could be that depressed and/or dissatisfied priests leave the priesthood; it could be that priests' vocational satisfaction increases over time; or there could be other explanations, as well. Again, we encourage researchers to explore this finding in more detail.

The current study, then, answers some questions, but as expected, raises others. Given the worrisome rates of depression among Roman Catholic secular clergy, it is incumbent upon those who select, train, work and live with, and supervise those clergy that such

Pastoral Psychology, Vol. 54, No. 2 (November 2005): pg. 139-155. DOI. This article is C Springer and permission has been granted for this version to appear in e-Publications@Marquette. Springer does not grant permission for this article to be further copied/distributed or hosted elsewhere without the express permission from Springer. 
research continue. Only when we understand what contributes to priests' distress, as well as their satisfaction, will we know how to reduce the former and increase the latter.

Acknowledgements: We are grateful to Doug Byorth, President of Focus Logistics, for his financial support of this project. We also thank Alan W. Burkard, Ph.D., and Timothy R. Lannon, S.J., for their comments on an earlier draft of this article.

\section{First Page Author Notes}

1. Sarah Knox, Jessica Thull, and John P. Lombardo, School of Education, Marquette University.

2. Fr. Stephen G. Virginia, Tribunal of the Roman Catholic Diocese of Columbus, Ohio.

3. Address correspondence to Sarah Knox, Department of Counseling and Educational Psychology, School of Education, Marquette University, Milwaukee, WI 53201-1881; email: sarah.knox@marquette.edu.

\section{References}

American Psychiatric Association. (2000). Diagnostic and statistical manual of mental disorders (4th ed.). Washington, DC: Author.

Beeber, L. S., Shea, J., \& McCorkle, R. (1998). The Center for Epidemiologic Studies Depression Scale as a measure of depressive symptoms in newly diagnosed patients. Journal of Psychosocial Oncology, 16, 1-20.

Coyle, C. P., \& Roberge, J. J. (1992). The psychometric properties of the Center for Epidemiological Studies-Depression Scale (CES-D) when used with adults with physical disabilities. Psychology and Health, 7, 69-81.

Diener, E. (2000). Subjective well-being: The science of happiness and a proposal for a national index. American Psychologist, 55, 34-43.

Goodstein, L. (2003). New York Times conducts "most complete" survey to date on church's scandal. The New York Times,p.1.

Jepsen, D. A., \& Sheu, H.-B. (2003). General job satisfaction from a developmental perspective: Exploring choice-job matches at two career stages. The Career Development Quarterly, 52, 163-179.

Kenedy, J. P., \& Sons (Eds.). (2003). The official Catholic directory. New Providence, NJ: Reed Publishing.

Knight, R. G., Williams, S., McGee, R., \& Olaman, S. (1997). Psychometric properties of the Center for Epidemiologic Studies Depression Scale (CES-D) in a sample of women in middle life. Behaviour Research and Therapy, 35, 373-380.

Pastoral Psychology, Vol. 54, No. 2 (November 2005): pg. 139-155. DOI. This article is (c) Springer and permission has been granted for this version to appear in e-Publications@Marquette. Springer does not grant permission for this article to be further copied/distributed or hosted elsewhere without the express permission from Springer. 
Knox, S., Virginia, S. V., \& Lombardo, J. P. (2002). Depression and anxiety in Roman Catholic secular clergy. Pastoral Psychology, 50, 345-358.

LeNoir, L. M. (2001). Can the variables that explain marital satisfaction and stability also explain vocational satisfaction and stability in the Roman Catholic diocesan priesthood: An investigation into and application of the VSA model of marriage (Doctoral dissertation, Loyola College in Maryland, 2001). Dissertation Abstracts International, 62(2-A).

Pallone, N. J. (1969). Correlates of vocational satisfaction among nuns and brothers. National Catholic Guidance Conference Journal, 14, 5-20.

Peterson, C., \& Seligman, M. E. P. (2004). Character strengths and virtues: A handbook and classification. Washington, DC: American Psychological Association; New York: Oxford University Press.

Radloff, L. S. (1977). The CES-D scale: A self-report depression scale for research in the general population. Applied Psychological Measurement, 1, 385-401.

Richards, P. S., \& Bergin, A. E. (Eds.) (2000). Handbook of psychotherapy and religious diversity. Washington, DC: American Psychological Association.

Rossetti, S. J. (2004, September 13). Post-crisis morale among priests. America, 191, 8-10.

Scott, B., \& Melin, L. (1998). Psychometric properties and standardized data for questionnaires measuring negative affect, dispositional style and daily hassles. A nation-wide sample. Scandinavian Journal of Psychology, 39, 301-307.

Sharf, R. S. (2002). Applying career development theory to counseling (3rd ed.). Pacific Grove, CA: Brooks/Cole.

Spector, P. E. (1997). Job satisfaction: Application, assessment, causes, and consequences. Thousand Oaks, CA: Sage.

Virginia, S. G. (1994). Burnout among Roman Catholic secular and monastic clergy. Unpublished masters thesis. Xavier University, Cincinnati, $\mathrm{OH}$.

Virginia, S. G. (1998). Burnout and depression among Roman Catholic secular, religious, and monastic clergy. Pastoral Psychology, 47, 4967.

Weissman, M. M., Sholomskas, D., Pottenger, M., Prusoff, B. A., \& Locke, B. Z. (1977). Assessing depressive symptoms in five psychiatric populations: A validation study. American Journal of Epidemiology, 106, 203-241.

Zickar, M. J., Balzer, W., Wryobeck, J., \& Aziz, S. (2004). Role strain and social support among Roman Catholic Priests. Unpublished manuscript, Bowling Green State University.

Pastoral Psychology, Vol. 54, No. 2 (November 2005): pg. 139-155. DOI. This article is (c) Springer and permission has been granted for this version to appear in e-Publications@Marquette. Springer does not grant permission for this article to be further copied/distributed or hosted elsewhere without the express permission from Springer. 
NOT THE PUBLISHED VERSION; this is the author's final, peer-reviewed manuscript. The published version may be accessed by following the link in the citation at the bottom of the page.

\section{Appendix}

Table 1: Summary of Hierarchical Regression Analysis for SRI Items Predicting SE-D Score (Listwise $N=169$ )

\begin{tabular}{lcrc}
\hline \multicolumn{1}{c}{ SRI Item } & B & SE B & $\beta$ \\
\hline Step 1 & & & \\
$\quad$ Vocational Satisfaction & -4.021 & .404 & -.610 \\
Step 2 & -3.596 & .425 & -.546 \\
$\quad$ Vocational Satisfaction & -.862 & .314 & -.177 \\
$\quad$ Non-Duty Opportunity for Company with Other Priests & & & \\
Step 3 & -3.368 & .429 & -.511 \\
$\quad$ Vocational Satisfaction & -.851 & .310 & -.175 \\
$\quad$ Non-Duty Opportunity for Company with Other Priests & -.080 & .032 & -.150 \\
$\quad$ Years of Priesthood & -3.126 & .440 & -.475 \\
Step 4 & -.765 & .309 & -.157 \\
$\quad$ Vocational Satisfaction & -.073 & .032 & -.137 \\
$\quad$ Non-Duty Opportunity for Company with Other Priests & -.688 & .327 & -.133 \\
\hline Years of Priesthood & & & \\
$\quad$ Ease of Discussion About Work or Vocational Concern & & &
\end{tabular}

Table 2: Summary of Hierarchical Regression Analysis for VSI Items Predicting SRI Overall Vocational Satisfaction Question (Listwise $\mathbf{N}=$ 180)

\begin{tabular}{llll}
\hline \multicolumn{1}{c}{ VSI Item } & B & SE B & $\beta$ \\
\hline Step 1 & & & \\
$\quad$ Parish Activities & .423 & .065 & .439 \\
Step 2 & .336 & .064 & .348 \\
$\quad$ Parish Activities & .294 & .061 & .318 \\
$\quad$ Affirmation of God's Call to this Vocation & & & \\
Step 3 & .281 & .065 & .292 \\
$\quad$ Parish Activities & .231 & .063 & .249 \\
$\quad$ Affirmation of God's Call to this Vocation & .150 & .047 & .223 \\
$\quad$ Relationships with Fellow Clergy & & & \\
Step 4 & .221 & .067 & .229 \\
$\quad$ Parish Activities & .209 & .062 & .225 \\
$\quad$ Non-Duty Opportunity for Company with Other Priests & .150 & .046 & .223 \\
$\quad$ Relationships with Fellow Clergy & .229 & .082 & .185 \\
Opportunities to Help Others & & &
\end{tabular}

Pastoral Psychology, Vol. 54, No. 2 (November 2005): pg. 139-155. DOI. This article is (c Springer and permission has been granted for this version to appear in e-Publications@Marquette. Springer does not grant permission for this article to be further copied/distributed or hosted elsewhere without the express permission from Springer. 
NOT THE PUBLISHED VERSION; this is the author's final, peer-reviewed manuscript. The published version may be accessed by following the link in the citation at the bottom of the page.

Table 3: Summary of Hierarchical Regression Analysis for VSI Items and Sexual Abuse Question Predictign CES-D Score (Listwise $\boldsymbol{N}=197$ )

\begin{tabular}{|c|c|c|c|}
\hline VSI Item/Sexual Abuse Question & B & SE B & B \\
\hline \multicolumn{4}{|l|}{ Step 1} \\
\hline Affirmation of God's Call to this Vocation & -2.190 & .420 & -.350 \\
\hline \multicolumn{4}{|l|}{ Step 2} \\
\hline Affirmation of God's Call to this Vocation & -1.764 & .424 & -.282 \\
\hline Opportunities to Help Others & -2.083 & 574 & -.246 \\
\hline \multicolumn{4}{|l|}{ Step 3} \\
\hline Affirmation of God's Call to this Vocation & -1.541 & 426 & -.246 \\
\hline Opportunities to Help Others & -1.754 & 578 & -207 \\
\hline Relationships with Parishioners & -1.350 & .500 & -.183 \\
\hline \multicolumn{4}{|l|}{ Step 4} \\
\hline Affirmation of God's Call to this Vocation & -1.187 & 446 & -.190 \\
\hline Opportunities to Help Others & -1.724 & .571 & -.203 \\
\hline Relationships with Parishioners & -1.224 & 497 & -166 \\
\hline Relationships with Fellow Clergy & -.741 & .311 & -.164 \\
\hline \multicolumn{4}{|l|}{ Step 5} \\
\hline Affirmation of God's Call to this Vocation & -1.007 & .450 & -.161 \\
\hline Opportunities to Help Others & -1.521 & .573 & -.179 \\
\hline Relationships with Parishioners & -1.317 & 494 & -.178 \\
\hline Relationships with Fellow Clergy & -.692 & 309 & -.153 \\
\hline Mood Affected by Recent Sexual Abuse Scandal & -.952 & .438 & -.143 \\
\hline \multicolumn{4}{|l|}{ Step 6} \\
\hline Affirmation of God's Call to this Vocation & -.890 & .450 & -.142 \\
\hline Opportunities to Help Others & -1.321 & .577 & -.156 \\
\hline Relationships with Parishioners & -.986 & .517 & -.133 \\
\hline Relationships with Fellow Clergy & -.744 & 308 & -.164 \\
\hline Mood Affected by Recent Sexual Abuse Scandal & -1.001 & .435 & -.151 \\
\hline Preaching Activities & -1.022 & .503 & -.140 \\
\hline
\end{tabular}

Table 4: Summary of VSI Rotated Factor Analysis (Listwise $\mathbf{N}=\mathbf{2 0 4}$ )

\begin{tabular}{|c|c|c|c|}
\hline \multirow[b]{2}{*}{ VSI Item } & \multicolumn{3}{|c|}{ Factor } \\
\hline & External & Internal & Social \\
\hline Preaching Activities & .723 & & \\
\hline Share presence of God/goodness & 692 & & \\
\hline Teaching Activities & 686 & & \\
\hline Involvement in Sacraments & 614 & & \\
\hline Opportunities to Help Others & .586 & & \\
\hline Parish Activities & .564 & & \\
\hline Prayer Lifo & & .752 & \\
\hline Affirmation of God's Call to this Vocation & & 690 & \\
\hline Relationships with Fellow Clergy & & .664 & .479 \\
\hline Opportunities to Experience Transcendence & & .521 & \\
\hline Relationships with Parishioners & & & .752 \\
\hline Appreciated by Others & & & .716 \\
\hline Eigenvalue & 2.90 & 2.29 & 1.60 \\
\hline Variance Accounted For & $24.17 \%$ & $19.08 \%$ & $13.36 \%$ \\
\hline
\end{tabular}

Note. Item loadings of $<0.40$ have been omitted.

Pastoral Psychology, Vol. 54, No. 2 (November 2005): pg. 139-155. DOI. This article is @ Springer and permission has been granted for this version to appear in e-Publications@Marquette. Springer does not grant permission for this article to be further copied/distributed or hosted elsewhere without the express permission from Springer. 